\title{
THE EFFECT OF PRICE TARGETS ON THE COMPOSITION OF CEO PAY
}

\author{
Giuliano Bianchi ${ }^{1}$ \\ Ecole hôtelière de Lausanne, HES-SO // University of Applied Sciences Western Switzerland \\ Lausanne, Switzerland \\ giuliano.BIANCHI@ehl.ch
}

December, 2015

\begin{abstract}
Objective: This paper analyzes the impact of price targets from the IBES Detail Price History Target database on CEO compensation retained from Execucomp.

Methods: The two databases are merged at fiscal year frequency and an OLS regression with fixed effect is used to analyze the impact of price target on CEO compensation.

Results: The analysis reveals that analysts' price targets affect top executives' compensation: when analysts predict a growth in the share price for a company, the compensation package tilts toward stock options, when analysts forecast a drop in the share price, the compensation package tilts toward cash-based compensation and restricted stocks.

Conclusion: I argue that the result is more aligned with the managerial power model of compensation (which assumes the board of directors maximizes managers' compensation) than with the arm's length bargaining model (that states that managers' compensation is set to maximize shareholders' profit).
\end{abstract}

Keywords: executive compensation, price targets, corporate governance, ownership structure.

JEL: G13, G32, G34, G38, J33

\footnotetext{
${ }^{1}$ Corresponding Author: Giuliano Bianchi, Ecole hôtelière de Lausanne, Route de Cojonnex 18, 1000 Lausanne, Switzerland. Email: giuliano.bianchi@ehl.ch.
} 


\section{Introduction}

In this paper, I analyze the impact of an indicator, i.e. the likely future change in a firm's stock price on executive compensation. The indicator involves market analysts' expectations regarding the firm's share price in the next year as reported by the Institutional Broker Estimate System in its Detail Price History Target database. My main finding is that analysts' forecasts of the share price affect the structure of CEO compensation. Specifically, I find that analysts' price targets alter the composition of executive pay. When analysts forecast a rise in the share price for a firm, its compensation package tilts toward stock options. When analysts forecast a fall in the share price, the compensation package tilts toward cash-based compensation and restricted stock. The share price that analysts expect for a firm in the future has not to my knowledge been previously analyzed in studies of executive compensation.

The IBES Detail History Price Target data file reports companies' price targets from different analysts. Analysts' announcements are public information available to the board of directors and to shareholders as opposed to private information that managers can use to structure compensation for their benefit at the expense of shareholders. Managers may influence analysts' recommendations but since analysts' announcements are in the public domain, managers have less room to manipulate their compensation accordingly without the board of director's knowledge. Thus, the relationship between CEOs' compensation and analysts' price targets can provide further insights into the determinants of executive pay. In particular, the results can be interpreted under both the arm's length bargaining model, which assumes that the board of directors set top executives' pay to maximize shareholders' interests, and the managerial power model, which assumes the board of directors maximizes managers' compensation within constraints imposed by social costs and market penalties 
(Bebchuk and Grinstein, 2005). I argue that the managerial power model is the model that best fits with the new these new findings.

\section{Background}

Shareholders hire executives to act in their best interest. But managers have information that shareholders do not have, and they can exploit that information for their benefit. Thus, managers' interests are generally not fully aligned with shareholders' interests. Proponents of the principal-agent model of pay have stressed the ways in which a board of directors can institute incentive schemes to reduce the agency costs from separation of ownership and control and improve shareholder value. Ideally, such compensation systems align executives' interests with those of shareholders (Jensen and Meckling, 1976; Fama and Jensen, 1983; Eisenhardt, 1989; Dalton et al., 2007). In particular, the principal-agent theory suggests that the agency cost arising from separation of ownership and control can be mitigated through stock-based compensation that links executive pay to the share price of the firm, which reflects company performance. Consistent with such arguments, firms have increased stockbased compensation considerably in the last decades, particularly stock options.

A board that seeks to motivate executives with different forms of pay should equate the marginal cost to the firm of additional options or other forms of compensation with the extra benefits from inducing executives to make decisions in the shareholders' interests. Adherents of the view that executive compensation has a substantial positive impact on the economic performance of firms believe that performance depends critically on managerial skills, and that boards negotiate executive compensation to create incentives for a manager to grow the share price, which they take as the best measure of the long-term value of a firm. Managers whose skill level is higher are more likely to accept stock options than less-skilled managers. 
Critics of executive compensation argue that because executives influence membership on a board that boards make decisions about compensation that benefit executives at the expense of shareholders, and/or that executives find ways to manipulate whatever incentive system the board sets to enrich themselves. Bebchuk and Grinstein (2005) notes that the increase in equity-based compensation "has not been accompanied by a substitution effect, i.e. a reduction in non-equity compensation", which suggests that the options may simply be a new mode for executives to enrich themselves. But without evidence on the true marginal value of an executive it is also possible that their value increased over time and that firms increased equity-based compensation in line with increased value. The US system of basing executive options on the share price of a firm rather than on the share price of the firm relative to that of competitive firms or to the broader stock market is also suggestive of a system run for the benefit of executives. Under the US system, management can profit from fortuitous increases (i.e. good luck) in the firm's share price that have nothing to do with their effort (Bertrand and Mullainathan, 2001), by general inflation in share prices, or by using their inside information to time the receipt of options in ways that would most benefit them.

Summarizing the debate, Bebchuk and Jesse (2003) divide adherents and critics of executive compensation into two opposing camps. On the one side are adherents to "the arm's length bargaining model" that posits that boards of directors try to maximize shareholders' interests subject to the constraint set by executives' supply behavior -paying the amount and nature of compensation that is necessary for potential executives to accept a job and to spend their time and effort finding ways to increase the value of shares. The package is the result of arm's length transaction between the board seeking the best deal for shareholders and executives selling their skills. The ideal board model of setting executive compensation posits that the firm's board of directors bargain at arm's length with executives for a stock-based 
incentive scheme that ideally induces management to maximize shareholders' wealth. Motivated by the desire to better align compensation and shareholder value, major firms shifted executive pay from cash-based salaries to stock options from the 1980 s to the 2000 s. In the late 2000 s, they began to shift stock-based compensation from options to restricted stock grants.

On the other side of the spectrum is the "managerial-power" model. Under the managerial power model the board of directors seeks the most favorable compensation for executives under the threat of market penalties and social costs that rise when it adopts excessively favorable arrangements for executives (Bebchuk and Grinstein, 2005). The managerial power model questions the efficacy of stock-based incentives to solve the principal agent models and views incentive schemes as part of the agency problem itself. It argues that boards of directors - whose members may be in part chosen by executives and in which executives serve - do not bargain ideally on behalf of shareholders. Bebchuk and Jesse (2003) explore how the two models influence top executive compensation and direct their attention to aspects of executive pay determination that the arm's-length bargaining model cannot explain. They argue that the observed pay structure is most likely a compromise between market forces, which mitigates managerial rent-seeking, and managerial-power that favors top executive compensation. Analyzing the growth of manager compensation during the period 1993-2003, Bebchuk and Grinstein, (2005) note that equity-based compensation, consisting largely of stock options, increased considerably without any reduction of cashbased compensation. This raises the possibility that the complexity of options may have given executives a way to increase their compensation. Bebchuk and Grinstein (2005) find that both models help explain the increase in top executives' compensation. In their recent review of the executive compensation literature Frydman and Jenter (2010) reach a similar conclusion: "both managerial-power and competitive market forces are important determinants of CEO 
pay, but neither approach is fully consistent with the available evidence."

Murphy (2002) questions the ability of both the arm's length bargaining model and the managerial power model to fit the observed pattern of executive pay, stressing that there are measurement and modeling issues in comparing the value of stock options to salary or other cash-based pay. In particular, he shows that both models can explain the rise in CEO compensation under different assumptions but highlights inconsistencies between the evidence and the managerial power model. He favors a "perceived-cost view", which assumes that risk-adverse executives cannot hedge the risk of options (Murphy, 2002; Hall and Murphy, 2003). In particular, Hall and Murphy (2002) have argued that the Black-Scholes formula traditionally used to value stock option compensation overstates the value of options granted to executives. The Black-Scholes method assumes that the holders of options are risk neutral inasmuch as they can hedge the risk by short selling and diversifying their portfolio. If managers cannot hedge the risk because they have to keep their compensation aligned with firms' performance, they face a higher risk-related cost for exchanging cash-compensation for options. Murphy (2002) claims that executives are willing to exchange cash for options but in exchange for a risk premium. In other words, the Black-Scholes formula overvalues the value of stock options leading companies to underestimate the cost of granting options to executives. The "perceived-cost view" yields a conclusion that is similar to those offered by the managerial power model but with different policy implications.

Both the managerial-power and the arm's length bargaining models explain CEO pay (Bebchuk and Jesse, 2003; Bebchuk and Grinstein, 2005; Frydman and Jenter, 2010.

On the flip side, Bettis et al. (1999) provide evidence that executives hedge some options. There are, moreover, other forms of compensation policy that mitigate the opportunity cost of holding options instead of cash. When options go underwater companies often seek to re-align incentives by granting extra options (makeup grants), or by deleting 
underwater options and granting new ones in a " $6 \& 1$ exchange" no earlier than six months and one day, where the timing reflects accounting rules. Less common is the practice of repricing options by reducing the exercise price of existing underwater options. There is a danger that such re-alignment policies may have adverse effects on incentives since they compensate executives despite poor performances. To the extent that firms adopt such policies, they reduce the risk of receiving stock-based compensation instead of cash, which mitigates against the Hall and Murphy (2002) critique. Balachandran et al. (2004) find that firms are more likely to grant extra options without changing salaries when the firm performs poorly and existing options go under water.

The shift from cash-based compensation to options is also impacted by the tax advantages of paying large amounts of compensation as stock options rather than as cash, which is beneficial to firms. Under Section $162 \mathrm{~m}$ of the US tax code a firm can deduct incentive pay to executives over $\$ 1$ million as a cost of business but it cannot deduct a salary over $\$ 1$ million as a cost of business. Since paying executives in a way that minimizes taxes is in the interest of shareholders, an optimal board may choose to pay with options even if the options do not truly align management and shareholder interests. As some executives have gained massively from options even when their firm is doing poorly, shareholders and the public have become more critical of options. Kuhnen and Niessen (2012) shows that in the recent shift out of stock options to less contentious forms of compensation such as salary is associated with more negative press toward options.

In short, there are several factors associated with the allocation of compensation between cash-based and stock-based pay: shareholder desire to align management interests with their own; tax advantages of compensation beyond a million dollars, publicity and shareholder concern over excessive pay, and the risk trade-off of executive compensation in options to compensation in cash or stock. 
This paper contributes to the ongoing literature by showing that analysts' forecasts of the share price affect the structure of CEO compensation. When analysts forecast a rise in the share price for a firm, a CEO's compensation package tilts toward stock options. When analysts forecast a drop in the share price, the compensation package tilts toward cash-based compensation and restricted stock. I argue that this pattern is more readily explicable by the managerial power model than the arm's length bargaining model of the determination of executive compensation.

Table 1 summarizes the main compensation models discussed in the literature.

Table 1: The three opposing camps of thought in the existing literature.

\begin{tabular}{|l|l|l|}
\hline $\begin{array}{l}\text { The arm's length } \\
\text { bargaining model }\end{array}$ & Managerial-power model & Perceived-cost view \\
\hline $\begin{array}{l}\text { The boards of directors } \\
\text { try to maximize } \\
\text { shareholders interests } \\
\text { subject to the constraint } \\
\text { set by executives' pay. }\end{array}$ & $\begin{array}{l}\text { The board of directors seeks } \\
\text { the most favorable } \\
\text { under the threat of market } \\
\text { penalties and costs. }\end{array}$ & $\begin{array}{l}\text { Risk adverse executives } \\
\text { cannot hedge the risk of } \\
\text { options, thus managers } \\
\text { ask for a risk premium to } \\
\text { hold stock-based } \\
\text { compensation. The } \\
\text { "perceived-cost view" } \\
\text { yields a conclusion } \\
\text { similar to those offered } \\
\text { by the managerial power } \\
\text { model but with different } \\
\text { policy implications. }\end{array}$ \\
\hline $\begin{array}{l}\text { Both managerial-power and arm's length bargaining } \\
\text { model explain CEO pay (Bebchuk and Jesse, 2003; } \\
\text { Bebchuk and Grinstein, 2005; Frydman and Jenter, 2010). }\end{array}$ & $\begin{array}{l}\text { Murphy, 2002; Hall and } \\
\text { Murphy, 2003. }\end{array}$ \\
\hline
\end{tabular}

\section{Data}

My analysis uses two data sets to examine how analysts' targets affect the composition of compensation: Execucomp and IBES Detail History Price Target data file. I focus on US firms only. 


\subsection{Execucomp}

I collected detailed information on top manager compensation for US companies from the Standard \& Poor's Executive Compensation data set (Execucomp) for fiscal year 1999 through fiscal year 2010 (133,450 observations). Execucomp collects detailed information on top executive pay directly from companies' annual proxy statement (DEF 14A SEC). Most companies report data on only five executives but some companies voluntarily report more executives. I conducted my analysis on CEOs only (21,858 observations). The variable CEOANN provided by Execucomp indicates which officer served as CEO for the entire or most of the fiscal year.

I take the following information from Execucomp: the dollar value of total compensation (Execucomp variable TDC1), the dollar value of salary (Execucomp variable SALARY in thousands of dollars), bonus (Execucomp variable BONUS in thousands of dollars), the value of stock options awarded (Execucomp variable BLK_VALUE until 2006, renamed as OPTION_AWARD_FV thereafter), the value of stock awards (Execucomp variable RSTKGRANT before 2006, renamed STOCK_AWARD_FV thereafter), the Long Term Incentive Payout (LTIP), Deferred Compensation Earnings Reported as Compensation (DEFER_RPT_AS_COMP_TOT, available only after 2006) and All Other Total (ALLOTHTOT, which I substitute with OTHCOMP after 2006 to be consistent with the new definition of TDC1).

In 2006, the FAS123R changed the reporting rules. Under the new rules, companies have to report the estimated fair value of the stock options granted in the proxy statement. Different evaluating methods are permitted, including the Black-Scholes and the binomial options pricing model. Prior to 2006, Execucomp provided its own fair value estimate for 
stock options granted using a non-standard Black-Scholes formula. Therefore, the time series includes the value of stock options granted estimated by Compustat from 1996 to 2005, and the value of stock options evaluated by each company since 2006. The reason Execucomp used a non-standard Black-Scholes formula to value stock options and the SEC allows firms to use their own methods of evaluation is that the Black-Scholes formula is designed for European options, which can be exercised only at the expiry date, whereas almost all options traded in America are American options, which can be exercised any time up to the expiration date $^{2}$ (Bodie et al., 2001). Since holders of the options have greater leeway over when to exercise them they generally tend to have higher value than the Black-Scholes formula. Indeed, empirical analysis shows that the Black-Scholes formula tends to undervalue options deeply in the money but overvalue call options deeply underwater (Bodie et al., 2001). Geske and Roll (1984) provide evidence that this result is due to the fact that the Black-Scholes model does not take into account the opportunity to exercise American options earlier, versus European ones. Regarding the latter point, Compustat computes the Black-Scholes option values by using $70 \%$ of the stated life. For instance, if the time to maturity is 10 years, Compustat reduces it to 7 years. Whaley (1982) shows that more complicated models do better than Black-Scholes by taking into account early exercise. However, Bodie et al. (2001) stress that many empirical studies show that Black-Scholes is a fair approximation of the actual price of traded options. There was another change in the SEC's compensation disclosure rules adopted in 2006 that affects the data. Before 2006, there was a distinction between short-term incentive pay and long-term incentive pay (LTIP). In 2006, the SEC introduced a new terminology to isolate executive incentive compensation paid in cash: nonequity incentive. The new category includes incentives awarded in cash that are earned if

\footnotetext{
${ }^{2}$ Also, most options granted to CEOs can be exercised only after a certain period of time (vesting period). They are referred as "Bermudian" Options since they are a hybrid between American Options and European Options (Rubinstein, 1995).
} 
management meets certain performance criteria. Prior to this, firms reported all short-term incentive paid in cash as part of the bonus component of CEO compensation. Thus the new terminology shifted cash compensation previously reported under the label "bonus" to the new label "non-equity incentive". Hence, after 2006, "bonus" defines cash earned by officers who met criteria that were not disclosed, while it no longer reports LTIP. Finally, in 2006, Execucomp also changed the way total compensation is calculated. Before 2006, total compensation (TDC1) was calculated as the sum of salary, bonus, restricted stock granted, stock options, long-term incentive payout and other forms of compensation. After 2006, total compensation was calculated as the sum of salary, bonus, stock awarded, stock options, nonequity incentive plan compensation, deferred compensation earnings reported as compensation and other compensation.

I use yearly companies' official Ticker and their CUSIP number to match them, from the Execucomp database, to the Center for Research in Stock Prices' databases (CRSP). CRSP allows me to assign the PERMNO (permanent security identification, that is unchanged during the time) for each firm. I drop companies that were not matched with CRSP $(2,855$ transactions). I use the 4-digit SIC-codes to assign each firm to one of the 49 industries as defined by French and Fama regulations.

Figure 1 shows the amount of nominal dollars in each component of compensation for CEOs in the Execucomp files working in companies for which I was able to obtain information on analysts' price targets. The figure stacks the data for each form of pay, and thus provides a picture of both the level and composition of CEO pay from fiscal year 1999 to 2010 for Execucomp companies for which IBES data file reports analysts' price targets. The top of each bar measures the average level of total compensation. The different elements show the average level of each component: salary, bonus, stock options, shares, long term incentive payout, deferred compensation, non-equity incentive plan and other forms of compensation. 
Total CEO compensation increased from slightly more than \$5 million in 1999 to $\$ 5.5$ million in 2010. The increase was substantiale from 1999 to 2000 during the dot.com boom. Total compensation reached a maximum in 2000, and then declined through 2003 after which it started to rise again. However, nominal compensation in 2010 was still lower than in 2000. The increase in executive compensation over the entire period took the form mainly of an increase in stock-based compensation. Most of the increase in stock-based compensation took the form of increased stock options but after 2000 stock-based compensation shifted from options to restricted stock grants ${ }^{3}$.

\section{Figure 1: Evolution of both the level and composition a of representative CEO's compensation in nominal dollars for fiscal year 1999 to 2010.}

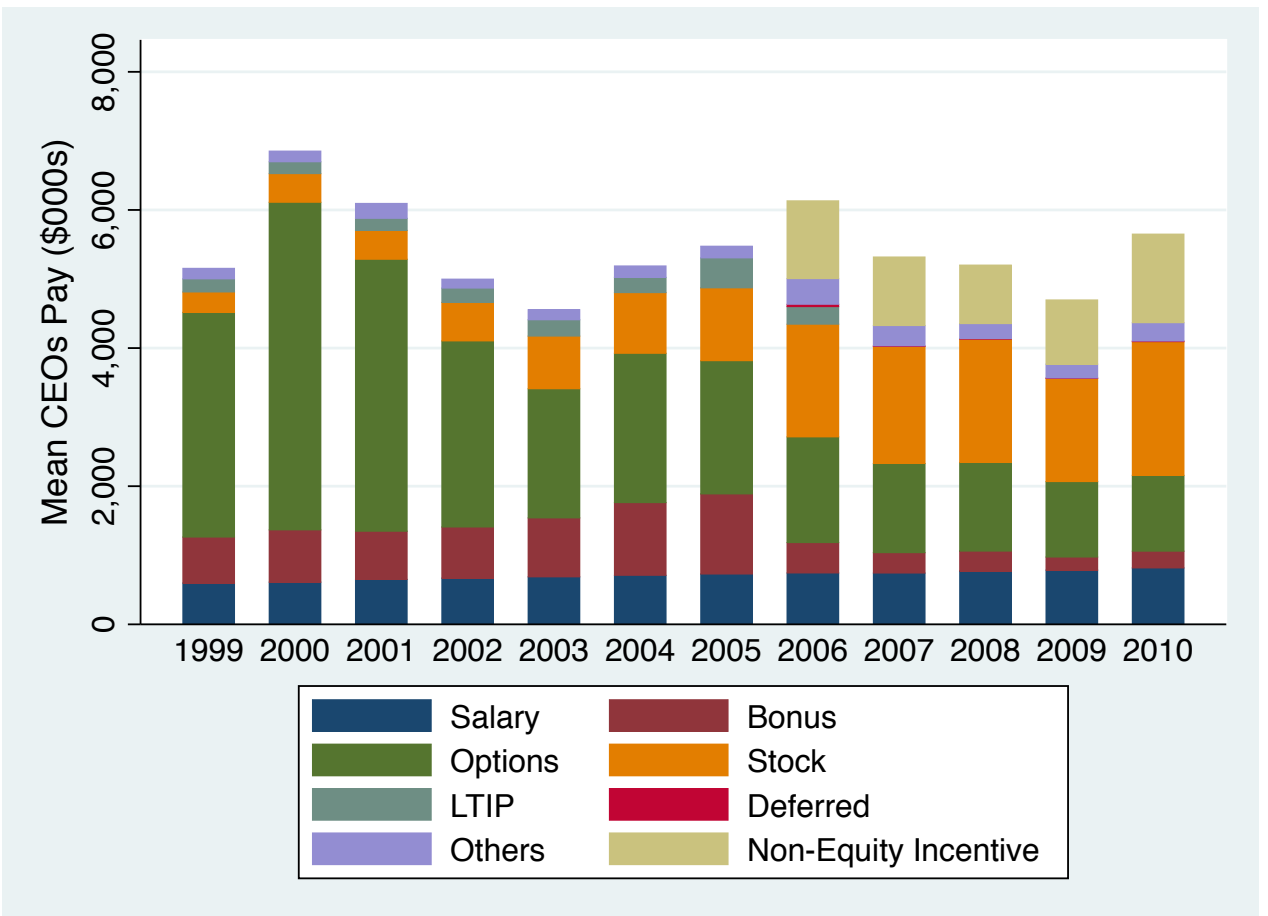

\footnotetext{
3 Because the Execucomp sample of firms changes over time, it is possible that the averages in figure 1 are distorted, at least in terms of firms' experiences, by the changing composition of the sample. To see how salaries of an unchanged sample of firms changed over the period, I took firms that appeared in consecutive years of Execucomp and calculated the yearly change in total compensation year by year. For instance, if a firm in Execucomp reported total CEO compensation of $\$ 943,625$ in 1999 and total CEO compensation of $\$ 1,821,739$ in 2000 , I computed the difference between the two years. I averaged the differences across all the firms that had data on compensation in both years. I found that the overall pattern of change closely mimics the changes shown in figure 1, which implies that the averages in figure 1 are not distorted because of a change in composition of the sample (data not reported).
} 


\subsection{Institutional Broker Estimate System (IBES) Detail History Price Target data file}

I link this compensation data to the price target data obtained from the Institutional Broker Estimate System (IBES) Detail History Price Target data file, which provides statistics on analysts' price targets - "the projected price level forecast by an analyst within a specific time horizon" (Glushkov, 2009, p. 6).

Specifically, the IBES Price Target data file records the following variables: analysts' price targets level, analysts' name, the company he/she works for, company for which he/she issues the target price, the horizon-period, the day the price target was announced and when it became active in the IBES data file, the company currency and whether or not the company is a US firm. The price targets are available from March 1999 to the present ${ }^{4}$. I start with $2,835,823$ observations. I use CUSIP and the official TICKER provided by IBES to infer the PERMNO code on CRSP. I drop 1,947,279 observations for which it was not possible to assign a PERMNO. For every PERMNO and announce date, I obtain the stock's closing price at the announcement date from CRSP. I eliminated 91,382 observations for which it was not possible to assign a closing price or the stock closing price was missing. The targets cover different horizons expressed in months, but more than $90 \%$ of price targets have a 12 -month horizon $^{5}$, so I limit my analysis to those targets (losing 16,313 observations). I use the adjusted file data set (which IBES calls "normalized") that adjusts value for various corporate actions, like splits of stocks and dividend, and that is comparable across currencies. Since I restrict my analysis to price targets expressed in U.S. Dollars, I eliminate 22,615 observations for which the price target was express in a currency different from USD. I use CRSP/Compustat Merged dataset to infer for each permanent security identification number

\footnotetext{
${ }^{4}$ With the exception of one observation dating 1970.

${ }^{5}$ Approximately $98 \%$ in my subsample.
} 
(PERMNO) the corresponding variable FYR (indicating the months in which the fiscal year ends). I am thus able to link the CRSP permanent security identification number (PERMNO) with the variable FYR provided by Compustat and allocate each price target announcement to the corresponding fiscal years from 1998 to $2010^{6}$. If no FYR information is available I assume that the fiscal year coincides with calendar year, since $3 / 4$ of S\&P500 companies have a calendar year fiscal year (Wharton Research Data Services, n.d.). The reason I transform the data into a fiscal year basis is that the information in Execucomp is on a fiscal year basis ${ }^{7}$ I end up with 758,157 price target announcements occurring from fiscal year 1999 to 2011.

I use summary measures to indicate the likely direction of future share prices, which will determine the expected value of stock options and shares. The explanatory variable of interest in this analysis is the fiscal year average of the difference between the price target and the stock's closing price, which I label PT. I calculate this variable by subtracting from the natural logarithm of the price target the natural logarithm of the stock closing price at the announcement day obtained from CRSP. I then compute the average difference between the natural $\log$ of the price target and the natural $\log$ of the stock's closing price for the fiscal year ${ }^{8}$

I use analysts' announcements since they are public information available to the board of directors and to shareholders as opposed to private information that managers can use to structure compensation for their benefit at the expense of shareholders. In fact, it might be expected that managers influence analysts' recommendations and/or anticipate them.

\footnotetext{
${ }^{6} 77$ price target announcements occurred in the calendar year 1999 are assigned to fiscal year 1998.

${ }^{7}$ The merging between Compustat and IBES has one major problem: information reported in the Compustat (i.e. FYR) are reported at fiscal year frequency, while IBES information are reported at daily frequency. To assign the right FYR to each price target announcement, I merge information reported in Compustat by PERMNO and fiscal year. So, for instance, if a company has one announcement on the 12/31/2000, I look at the month in which the fiscal year ends (FYR) for the fiscal year 2000.

${ }^{8} \mathrm{I}$ ignore $0.006 \%$ price targets that report a forecasted value of zero for the following year. However, as a robustness test I create an alternative explanatory variable defined as the fiscal year average of the difference between the price target and the stock's closing price, which gives similar results.
} 
However, public information gives managers less room to manipulate their compensation than private information and if a manipulation occurs, the board of directors is most likely aware of analysts' expectations. Thus, if CEO pay is set according to analysts' price targets, it is likely done with the acknowledgement of the board.

The goal of my analysis is to use the price target data as a new explanatory variable in analyzing executive compensation. For price targets to affect decisions about CEO pay, there must be real information in the targets about future share prices. The question of whether or not forecasts of stock prices are useful indicators of future share prices has long been an issue of debate in the financial forecast literature. Using new statistical methods Granger (1992) points out that while there are no general profitable trading rules there is some forecastability in share prices and he outlines a critical survey of the methods used to forecast price.

Using IBES International Detail files, Bilinski et al. (2013) find that it is reasonable to rely on analysts' predictions. The authors find that some analysts have superior forecasting ability and reject the notion that price targets are "just for show" as the popular press claims. Intuitively, when analysts announce an increase (decrease) in share price, the share price moves in the predicted direction. An alternative test of the accuracy of analysts' price target announcements is to see how the stock market responded to the announcements. Womack (1996) studied the market reaction to analysts' recommendations and found that positive recommendations are associated with positive returns in the three-day window around the announcement. Asquith et al. (2005) also finds that the market reacts in a short period of time to price target announcements. Overall, the literature points out that analysts' price targets are reliable and therefore they can be used in setting executive compensation.

\section{Trade-off between cash-based compensation, restricted stock and stock options}


In this section, I test whether the board of directors takes into account price targets when setting CEO pay. I proceed as follows.

I first subdivide the CEO compensation components into three groups: cash-based compensation, restricted stocks and derivatives. The first category regroups the percentage of the compensation that takes the form of cash-based compensation. This category includes salary, bonuses, long-term incentives and non-equity incentives. Cash-based compensation is a subcategory whose value does not necessarily depend on stock performance. Cash-based compensation differs from stock-based compensation, which includes stock options and restricted stocks. The value of options and restricted stock depends on the stock price. However, even among stock-based compensation, a distinction between stock options and restricted stock is needed as the two forms of compensation have different payoffs. In fact, unlike restricted stock, the payoff of stock options is asymmetric: if the share price is higher than the strike price, the payoff of the stock options is the difference between the two variables but if the strike price is higher than the share price the payoff is zero.

I then test if and how the various forms of compensation react to price target expectations. The null hypothesis is that the board sets CEO compensation independently from the likely course of company share price. There are two alternative scenarios. The first is that the firm shifts CEO compensation toward stock options once prices are expected to rise since options are more desirable. In fact, most of the options awarded to executives are granted at the money. As a result, if analysts predict a rise in the share price, it is implied that those options will be de facto granted in the money. Symmetrically, if analysts expect share prices to fall the bulk of options, which are granted at the money, will most likely be out of the money. The same reasoning does not apply for cash-based compensation and restricted stock. Indeed, both cash-based compensation and restricted stock will still have value even if 
shares are expected to fall. Put in other words, stock options are a riskier form of compensation compared to cash-based compensation and restricted stock. The alternative policy would be for the firm to shift CEO pay away from stock options when it expects the share price to rise. In fact, since the options are expected to be more valuable in the future, a smaller number would give the executive the same value and incentive.

I focus on companies for which IBES issue price targets and Execucomp reports compensation details. Equation (1) defines the empirical model I estimate:

$$
Y_{i, t}=\alpha+\beta_{1} P T_{i, t}+\beta_{2} X_{i, t}+\partial y r_{t}+\lambda_{i}+\varepsilon_{i, t}
$$

$Y_{i, t}$ stands for the form of compensation under examination, namely cash-based compensation, stock options and restricted stock. In particular, $\mathrm{CBC}_{\mathrm{i}, \mathrm{t}}$ is the share of the executive's pay package that takes the form of cash-based compensation as a percentage, and it is defined as one less the sum of stock options and stock award divided by total compensation as reported by Execucomp (TDC1), multiplied by 100 . OPTIONS $i, t$ is similarly defined as the share of CEO pay that takes the form of stock options and it is computed as the fair value of options granted divided by total compensation (in percentage). Finally, STOCK $K_{i, t}$ is defined as the value of the share awarded to the CEO divided by total compensation (in percentage).

The explanatory variable of interest in this analysis is the fiscal year average of the difference between the natural logarithm of the price target and the natural logarithm of the stock closing price, which I label PT. I use the Compustat variable FYR, which measures the month in which a given firm's fiscal year ends, from Execucomp, to allocate each closing price and price target to the right fiscal years from 1999 to 2010 . I also include a vector of measures of the financial and economic characteristics of the firm, using institutional data 
reported by the Compustat_CRSP Merge database:

- SALE: is the natural logarithm of the gross sales or of the amount of billing for regular sales in thousands of dollars at time $t$.

- CHSR: stands for common/ordinary shareholders at time $t$.

- FEMALE: a dummy variable taking the value of one if the CEO is a woman at time $t$.

- AGE: indicate the age of the CEO at time $t$.

- $y r$ stands for time dummies for each fiscal year from 1999 to 2010.

- $\quad \lambda_{i}$ is the firm fixed effect.

Table 2 summarizes the results of an OLS (ordinary least square) regression of equation (1) in which I include company fixed effects. The econometric software I use to run the OLS regression with fixed effects is Stata. The estimated coefficient of the PT variable measures the effect of share price expectancy on CEO stock-based compensation.

First of all, the estimates show that price target matters in compensation. In all specifications price target has a significant impact on the various forms of compensation. Specifically, price target has a significant and positive impact on the percentage of compensation that takes the form of stock options.

Also, price targets have a significant and negative impact on the percentage of compensation given as restricted stock. Interestingly, in specification (6) analysts' expectations do not immediately affect the percentage of the pay taking the form of restricted stocks, but they do with a one-year lag. Finally, there is a trade-off between cash-based compensation (salary, bonus and "other compensation") and stock-based compensation. To summarize, the results show that the higher the expected profit (measured as the difference between the natural $\log$ of future price and the natural log of the stock closing price) the 
higher the percentage of CEO pay in stock options.

The R-squared value ranges from 0.14 to 0.21 for the models regressing stock-based compensation on price targets. The R-squared value drops considerably for the models regressing cash-based compensation on price targets, specifically it ranges between 0.022 and 0.025. The result might be due to the fact that cash-based compensation is generally not linked to stock prices, and thus, price targets have less explanatory power. On the contrary, as the value of restricted stock and options depends on the share price, price targets' explanatory power is relatively higher.

Some of the other regression coefficients also deserve attention. Older CEOs receive greater share pay in cash-based compensation. The results also show that the gender of the CEOs does not significantly affect the share of compensation in the form of cash-based compensation and that gender does not seem to influence the form in which managers are paid.

Could the relation between analysts' price target and stock options result from reverse causality? Stock options are granted with the purpose of giving the CEO an incentive to execute policies that will boost the share price. It is possible that analysts take into account CEOs' compensation when issuing price targets on the assumption that a greater incentive does in fact raise the share price a year later. But such an interpretation runs into three difficulties. 
Table 2: Multivariate analysis of the effects of price targets on CEOs compensation for the period from 1999 to 2010 . Estimates are reported. *, **, *** indicate significance at $10 \%, 5 \%$ and $1 \%$ levels respectively. The t-statistic are reported in parentheses.

\begin{tabular}{|c|c|c|c|c|c|c|c|c|c|}
\hline & (1) & (2) & (3) & (4) & (5) & (6) & (7) & (8) & (9) \\
\hline & OPTIONS & OPTIONS & OPTIONS & STOCK & STOCK & STOCK & CBC & $\mathrm{CBC}$ & $\mathrm{CBC}$ \\
\hline \multirow[t]{2}{*}{ PT } & $5.242 * * *$ & $4.984 * * *$ & $6.533 * * *$ & $-3.011 * * *$ & $-2.495 * * *$ & -1.282 & $-2.232 * * *$ & $-2.866 * * *$ & $-5.251 * * *$ \\
\hline & $(6.51)$ & $(5.55)$ & (5.14) & $(-4.60)$ & $(-3.32)$ & $(-1.19)$ & $(-2.60)$ & $(-2.97)$ & $(-3.86)$ \\
\hline \multirow[t]{2}{*}{ PT_1 } & & & 0.004 & & & $-2.250 * *$ & & & $2.246^{*}$ \\
\hline & & & $(0)$ & & & $(-2.33)$ & & & (1.84) \\
\hline \multirow[t]{2}{*}{ SALE } & -0.175 & -0.632 & -0.641 & $1.110^{* *}$ & 0.668 & 0.745 & -0.935 & -0.0590 & -0.104 \\
\hline & $(-0.27)$ & $(-0.89)$ & $(-0.87)$ & $(2.11)$ & (1.12) & (1.19) & $(-1.36)$ & $(-0.08)$ & $(-0.13)$ \\
\hline \multirow[t]{2}{*}{ CSHR } & 0.00297 & 0.00553 & 0.00517 & -0.00312 & -0.00501 & -0.00419 & 0.00015 & 0.00011 & -0.000985 \\
\hline & $(0.62)$ & (1.05) & $(0.94)$ & $(-0.80)$ & $(-1.14)$ & $(-0.90)$ & $(0.03)$ & $(0.02)$ & $(-0.17)$ \\
\hline \multirow[t]{2}{*}{ FEMALE } & -1.792 & -0.325 & -1.054 & $3.889 * *$ & $4.021 * *$ & $3.803^{*}$ & -2.098 & -3.604 & -2.749 \\
\hline & $(-0.80)$ & $(-0.14)$ & $(-0.44)$ & (2.12) & $(2.04)$ & (1.89) & $(-0.87)$ & $(-1.43)$ & $(-1.08)$ \\
\hline \multirow[t]{2}{*}{ AGE } & $-0.355 * * *$ & $-0.349 * * *$ & $-0.339 * * *$ & $-0.187 * * *$ & $-0.180 * * *$ & $-0.177 * * *$ & $0.542 * * *$ & $0.544 * * *$ & $0.516^{* * *}$ \\
\hline & $(-8.66)$ & $(-7.98)$ & $(-7.61)$ & $(-5.63)$ & $(-4.90)$ & $(-4.71)$ & $(12.42)$ & (11.54) & (10.84) \\
\hline \multirow[t]{2}{*}{ OPTIONS_1 } & & $0.144 * * *$ & & & & & & & \\
\hline & & $(15.78)$ & & & & & & & \\
\hline \multirow[t]{2}{*}{ STOCK_1 } & & & & & $0.149 * * *$ & & & & \\
\hline & & & & & $(15.32)$ & & & & \\
\hline \multirow[t]{2}{*}{ CBC_1 } & & & & & & & & $0.0447 * * *$ & \\
\hline & & & & & & & & $(4.87)$ & \\
\hline $\begin{array}{l}\text { YEAR } \\
\text { DUMMIES }\end{array}$ & yes & yes & yes & yes & yes & yes & yes & yes & yes \\
\hline $\begin{array}{l}\text { COMPANY } \\
\text { DUMMY }\end{array}$ & yes & yes & yes & yes & yes & yes & yes & yes & yes \\
\hline \multirow[t]{2}{*}{ CONSTANT } & $61.61 * * *$ & $42.33 * * *$ & $64.39 * * *$ & 5.737 & $9.633 * *$ & $9.030^{*}$ & $32.65 * * *$ & $22.14 * * *$ & $26.58 * * *$ \\
\hline & $(12.29)$ & (7.19) & (11.04) & $(1.41)$ & $(2.05)$ & $(1.83)$ & $(6.11)$ & $(3.65)$ & $(4.26)$ \\
\hline$N$ & 14278 & 12571 & 12266 & 14278 & 12571 & 12266 & 14278 & 12571 & 12266 \\
\hline$R^{2}$ & 0.14 & 0.165 & 0.147 & 0.201 & 0.212 & 0.19 & 0.022 & 0.025 & 0.022 \\
\hline
\end{tabular}


First, there is no compelling evidence that granting more stock options to executives is associated with future improvements in share prices. The empirical findings show that options produce a strong positive contemporaneous relation between share prices and executive compensation, not that greater options in $t$ are associated with a future increase in share prices from $t$ to $t+1$. Second, the analysts would have to know the compensation plans of the firm before they set their price target, which is highly dubious, as compensation committees are unlikely to divulge to outsiders their intended CEO package. Third, even if the analysts knew of companies' plans for regular scheduled options or extrapolated previous option grants, they cannot plausibly know about company plans regarding unscheduled options that are, by definition, granted at irregular intervals.

\subsection{Price targets and Non-equity incentives}

A component of CEOs' cash-based compensation that has received little analytic attention in the executive compensation literature is payments labeled "non-equity incentives". Non-equity incentives differ from other forms of cash-based compensation because executives have to meet certain pre-established and disclosed criteria to obtain them. The SEC introduced the term "non-equity incentives" in fiscal year 2006 to define cash incentives awarded if executives meet a disclosed pre-established target. The new terminology shifted cash compensation previously reported under the label "bonus" or LTIP to the new label "non-equity incentive" (if the criteria is disclosed) and to bonus (if the criteria is not disclosed). Before 2006, there was a distinction between short-term incentive pay (bonus) and long-term incentive pay (LTIP). LTIP is earned if a CEO meets criteria measured over a time

period longer than one year, typically three to six years (Larcker, 1983). The firm usually expresses the target in terms of earnings per share set at the beginning of the award period. 
Execucomp reports LTIP until 2006. Execucomp did not report when performance goals were established and thus when price targets could have affected LTIP compensation. As previously mentioned, prior to 2006 Execucomp defined cash-based compensation in addition to salaries as a bonus but in 2006 it added the non-equity incentive category and limited bonuses to cash compensation given for reaching undisclosed goals. The result is a discontinuity in the Execucomp data. In 2005, bonuses accounted for approximately $1 / 5$ of total compensation whereas in 2006 bonuses were less than 1/10 of total compensation. But bonuses, and nonequity incentives accounted for, on average, around 1/4 of CEOs' total compensation in 2010, which suggests that the categories as a group basically reflect the old bonus category.

The compensation earned as non-equity incentives is disclosed when the executive meets the performance criteria, not when the criteria is set. This is very different from stock options, where the firm discloses the options when they are granted. Price targets might affect non-equity incentives when the firm sets the criteria for earning the extra pay for meeting the criteria. But price targets cannot affect non-equity incentives when the firm reports the outcomes. To the extent that price targets affect the compensation labeled as non-equity incentives, it must do so with a lag. Balachandran et al. (2010) report that in most cases, firms set non-equity incentives annually based upon single year targets. Therefore, to estimate the possible impact of price targets on non-equity incentive, I examine the relationship between non-equity incentives and PT lagged one year.

Even with the lag, there could be a positive simultaneous correlation (but not causality) between the expected share price and non-equity incentive. For example, suppose that a company sets a non-equity incentive at time $t$-s. If at time $t$ the sector is booming, the executive will likely meet the performance criteria. If analysts issue a high price target for the company because they expect the boom to continue, we would obtain a positive correlation between share price and non-equity incentives even though there is no causal relation between 
them. A future price target cannot affect the terms of a non-equity incentive that were set a year earlier.

Table 3: Multivariate analysis of the effects of price targets on non-equity incentive for the period from 2006 to 2010. Estimates are reported. $*, * *, * * *$ indicate significance at $10 \%, 5 \%$ and $1 \%$ levels respectively. The t-statistic are reported in parentheses.

\begin{tabular}{|c|c|c|c|}
\hline & $\begin{array}{c}(1) \\
\text { NON- } \\
\text { EQUITY } \\
\text { INC }\end{array}$ & $\begin{array}{c}(2) \\
\text { NON-EQUITY } \\
\text { INC }\end{array}$ & $\begin{array}{c}(3) \\
\text { NON- } \\
\text { EQUITY } \\
\text { INC }\end{array}$ \\
\hline PT & $\begin{array}{c}-5.514 * * * \\
(-2.93)\end{array}$ & & \\
\hline $\mathrm{PT} \_1$ & $\begin{array}{c}-3.041 * * \\
(-1.98)\end{array}$ & $\begin{array}{c}-3.818 * * * \\
(-2.58)\end{array}$ & $\begin{array}{c}-3.753 * * \\
(-2.44)\end{array}$ \\
\hline $\begin{array}{l}\text { NON- } \\
\text { EQUITY } \\
\text { INC } 1\end{array}$ & & & - $0.116^{* * *}$ \\
\hline & & & $(-7.51)$ \\
\hline SALE & $\begin{array}{c}4.697 * * * \\
(4.61)\end{array}$ & $\begin{array}{c}4.506 * * * \\
(4.46)\end{array}$ & $\begin{array}{c}4.723 * * * \\
(4.52)\end{array}$ \\
\hline CSHR & $\begin{array}{c}-0.00537 \\
(-0.48)\end{array}$ & $\begin{array}{c}-0.00656 \\
(-0.59)\end{array}$ & $\begin{array}{c}-0.00439 \\
(-0.40)\end{array}$ \\
\hline FEMALE & $\begin{array}{l}5.600 * \\
(1.69)\end{array}$ & $\begin{array}{l}4.913 \\
(1.52)\end{array}$ & $\begin{array}{c}6.444^{*} \\
(1.91)\end{array}$ \\
\hline $\mathrm{AGE}$ & $\begin{array}{r}0.0870 \\
(1.36)\end{array}$ & $\begin{array}{c}0.0844 \\
(1.32)\end{array}$ & $\begin{array}{l}0.104 \\
(1.57)\end{array}$ \\
\hline $\begin{array}{l}\text { YEAR } \\
\text { DUMMIES }\end{array}$ & Yes & yes & yes \\
\hline $\begin{array}{l}\text { COMPANY } \\
\text { DUMMY }\end{array}$ & Yes & yes & yes \\
\hline CONSTANT & $\begin{array}{c}-17.08 * * \\
(-2.03)\end{array}$ & $\begin{array}{c}-16.00 * \\
(-1.92)\end{array}$ & $\begin{array}{c}-16.70 * \\
(-1.94)\end{array}$ \\
\hline$N$ & 5786 & 5838 & 5599 \\
\hline$R^{2}$ & 0.045 & 0.043 & 0.058 \\
\hline
\end{tabular}

To estimate the impact of price targets on the new variable "non-equity incentive" I proceed as follow. First, I define the dependent variable as the value of non-equity incentive divided by total compensation (in percentage). I then lag the main independent variable PT by one year on the notion that the firm could have taken account of that information in setting the terms that would determine non-equity pay a year later.

The results in table (2) show that the key estimated parameter in the table, which is the coefficient linking the lag of PT and non-equity incentives, is significantly negative. This 
confirms the table (1) finding that firms shift away from cash-based compensation for CEOs when the share price is expected to rise, even away from non-equity incentives. They trade non-equity incentive for forms of compensation, like stock options, that are even more tightly linked to increases in the share price.

Why does the firm treat non-equity incentives different from options? One might argue that CEOs regard non-equity incentives as stock options since they are earned only if a pre-set criterion is met. The higher the price target is, the higher the probability of reaching the goal so that the CEO would gain from both non-equity incentives and stock options. However, there is a major difference between options and non-equity incentives. The intrinsic value of an option depends exclusively on the share price: if the share price is above the strike price the option is in the money. If the price is below the strike price, the option is out of the money and cannot be cashed. Non-equity incentives, by contrast, are not exclusively linked to share price and may indeed relate to other performance goals. If the share price is expected to fall, a CEO might convince the board to set the criteria for her/his non-equity incentives based upon goals other than the share price - for instance market share or increases in sales. Finally, non-equity incentives are tax-attractive for companies. Firms can qualify for the deduction under section 162 of the tax code as long as they meet a pre-established performance goal of almost any kind: "a performance goal need not, however, be based upon an increase or positive results under a business criterion" (Section 162(m) of the Internal Revenue Code). If a firm's share price is expected to fall, the firm would set a criterion for a non-equity incentive to be a smaller drop in the share price than analysts expected.

\section{Discussion}

In this section, I examine how well the two main models of the determination of 
executive pay - the arm's length bargaining model, which assumes the board of directors contract top executives' pay to maximize shareholders' interests; and the managerial power model, which assumes the board of directors maximizes managers' compensation within constraints imposed by social costs and market penalties (Bebchuk and Grinstein, 2005), account for estimated relations between expected share prices and compensation. I argue that the relation between analysts' expectations and the composition of executive compensation might provide further insights into the determinants of executive pay.

Extant analysis of the substitution between cash-based pay and stock options in executive compensation have not analyzed the effect of analysts' expected changes in share prices on that substitution nor sought insight into the arm's-length bargaining and the managerial power models from such data. In particular, reviewing empirical studies, Frydman Jenter (2010) conclude that "both managerial-power and competitive market forces are important determinants of CEO pay" but leave open the question of their relative importance. Thus, the findings that firms switch from safer compensation such as cash-based compensation and restricted stock to riskier compensation such as stock options that are more highly tightly linked to increases in the share price when analysts expect their share price to rise, and switch from riskier compensation to safer compensation when analysts expect share prices to fall, can provide insights into which model best explains CEO compensation.

Under the managerial power model, a CEO will always seek ways to increase his or her income. They will try to exchange cash for stock options when they expect the share price to rise, whatever the causes of the rise, and prefer cash compensation when they expect the share price to fall. Hence, a board dominated by the CEO and management would always substitute cash or restricted stock for stock options according to share price targets.

Whether a board of directors acting under the arm's length bargaining model would trade stock options for other, less risky, forms of compensation according to price targets is 
less clear-cut. Suppose that the board of directors is fully able to screen a CEO's skills. One might argue that, being able to determine the CEO's value to the firm, the ideal board would simply seek the most efficient way to reward the CEO either using cash, stock or stock options according to the contingencies, such as the tax law. Switching from stock options to other form of compensation when the share price is expected to fall, the board would save shareholders from paying some costs. For instance, the board of directors might "inflate" the options' value to a desired amount by using price target information and take advantage of section $162 \mathrm{~m}$ of tax code for gaining a favorable tax treatment.

But the ideal board would still want to incentivize CEOs by binding CEO compensation to share price. The principal-agent arguments still remain: no matter how much managers' skills are worth, the board needs to align shareholders' interests with CEOs' personal interests. Therefore, the ideal board still needs to determine the right amount of stock options that maximizes CEO incentives and promotes shareholders' interests independently from other forms of compensation. Indeed, stock options might fall out of the money or even underwater if the share price tumbles. This makes stock options particularly risky for managers. This also makes stock options particularly attractive in case the share price rockets. Under both scenarios, the fact that options are more tightly linked with a rising share prices versus other forms of compensation they may create greater incentive for the CEO to drive the share price as high as possible. Other forms of compensation do not have the same characteristics: restricted stocks are still profitable even if the price falls while, in most cases, cash-based compensation is not linked to the share price.

Under the arm's length bargaining model, stock options are efficiently set to maximize CEOs' incentives independently from other forms of compensation. From this perspective, an ideal board should not contemplate a trade-off between stock options and a less risky form of compensation. In summary, the relation between IBES reports on analysts' price target 
announcements and executive compensation is more aligned with the managerial power model of executive pay than with the arm's bargaining model.

\section{References}

Asquith, P., Mikhail, M. B., \& Au, A. S. (2005). Information content of equity analyst reports. Journal of Financial Economics, 75(2), 245-282.

Balachandran, S., Kogut, B., \& and Hernal, H. (2010). Did executive compensation encourage extreme risk-taking in financial institutions?. working paper. Columbia University.

Balachandran, S., Carter, M. E., \& Lynch, L. J. (2004). Sink or swim? firms' responses to underwater options. Journal of Management Accounting Research, 16, 1-18.

Bebchuk, L., Jesse, M. (2003). Executive compensation as an agency problem. Journal of Economic Perspectives, 17(3), 71-92.

Bebchuk, L., \& Fried, J. (2004). Pay without performance: The unfulfilled promise of executive compensation Cambridge and London: Harvard University Press.

Bebchuk, L., \& Grinstein, Y. (2005). The growth of executive pay. Oxford Review of Economic Policy, 21(2), 283-303.

Bertrand, M., \& Mullainathan, S. (2001). Are ceos rewarded for luck? the ones without principals are. Quarterly Journal of Economics, 116(3), 901-932.

Bettis, J. C., Bizjak, J. M., \& Lemmon, M. M. (1999). Insider trading in derivative securities: An empirical examination of the use of zero-cost collars and equity swaps by corporate insiders. Working Paper. Yale School of Managment's Esconomics Research Network.

Bilinski, P., Lyssimachou, D., \& and Walker, M. (2013). Target price accuracy: International evidence. The Accounting Review: May 2013, Vol. 88, No. 3, Pages 825-851

Bodie, Z., Kane, A., \& and Marcus, A. (2001). Investments (Fifth ed.) The McGraw-Hill Companies.

Dalton, D. R., Hitt, M. A., Certo, S. T., \& and Dalton, C. M. (2007). Chapter 1: The fundamental agency problem and its mitigation. In Walsh, J.F. \& Brief, A.P. (Ed.), The academy of management annals (pp. 1-64). New York: Lawrence Erlbaum Associates.

Eisenhardt, K. M. (1989). Agency theory: An assessment and review. Academy of Management Review, 14(1), 57-74.

Fama, E. F., \& Jensen, M. C. (1983). Separation of ownership and control. Journal of Law \& Economics, 26(2), 301-326.

Frydman, C., \& Jenter, D. (2010). CEO compensation. Annual Review of Financial Economics, 2(1), 75-102.

Geske, R., \& Roll, R. (1984). On valuing american call options with the black-scholes european formula. Journal of Finance, 39(2), 443-455.

Glushkov, D. (2009). Overview of IBES on WRDS: Research and data issues, Data manuals. Wharton Research Data Services.

Glushkov, D. (2007). Working with analyst data: Overview and empirical issues, data manuals. Wharton Research Data Services.

Granger, C. W. J. (1992). Forecasting stock market prices: Lessons for forecasters. 
International Journal of Forecasting, 8(1), 3-13.

Hall, B. J., \& Murphy, K. J. (2002). Stock options for undiversified executives. Journal of Accounting \& Economics, 33(1), 3-42.

Hall, B. J., \& Murphy, K. J. (2003). The trouble with stock options. Journal of Economic Perspectives, 17(3), 49-70.

Jensen, M. C., \& Meckling, W. H. (1976). Theory of the firm: Managerial behavior, agency costs and ownership structure. Journal of Financial Economics, 3(4), 305-360.

Kuhnen, C. M., \& Niessen, A. (2012). Public opinion and executive compensation. Management Science, 58(7), 1249-2172.

Larcker, D. F. (1983). The association between performance plan adoption and corporate capital investment. Journal of Accounting \& Economics, 5(1), 3-30.

Murphy, K. J. (2002). Explaining executive compensation: Managerial power versus the perceived cost of stock options. University of Chicago Law Review, 69(3), 847.

Rubinstein, M. (1995). On the accounting valuation of employee stock options. The Journal of Derivatives, 3(1), 8-24.

Whaley, R. E. (1982). Valuation of american call options on dividend-paying stocks. Journal of Financial Economics, 10(1), 29-58.

Wharton Research Data Services. (n.d.). Modified black-scholes option valuation methodology. Retrieved from: Retrieved from: http://wrds-web.wharton.upenn.edu/wrds/

Wharton Research Data Services. (n.d.). Overview of executive compensation. Retrieved from: http://wrds-web.wharton.upenn.edu/wrds/

Womack, K. L. (1996). Do brokerage analysts' recommendations have investment value? Journal of Finance, 51(1), 137-167. 